\title{
THE CHARACTERISTICS OF GROUNDWATER TABLE AND SUBSIDENCE OF DEGRADED PEATLAND IN EX ICCTF PLOT CENTRAL KALIMANTAN
}

\author{
Muhammad Anang Firmansyah and Wahyu Adi Nugroho \\ Balai Pengkajian Teknologi Pertanian Kalimantan Tengah \\ email: anang.firmansyah75@yahoo,com
}

Diserahkan: 30 Juli 2020

Diterima: 24 Desember 2020

\begin{abstract}
Degraded peatlands typically have been cultivated by communities for agriculture. Ex ICCTF plot in Jabiren is considered as a degraded peatland since the area has been cultivated and drained for smallholder plantation. This study aimed to characterise the groundwater level and peat subsidence periodically over seven months of observation. It has been found that the groundwater level fluctuated from $50 \mathrm{~cm}$ to $150 \mathrm{~cm}$ below the peat surface, implying the deterioration of peat ecosystem. Based on the transect observation, the groundwater table seems to form a dome shape with the deeper level existed adjacent to the canal. The average peat subsidence was around 27 to $39 \mathrm{~cm}$ in cumulative since the subsidence stick installation. However, in the range of ten-month of observation, the peat subsidence was around $8.5 \mathrm{~cm}$. The subsidence was higher on the location adjacent to the canal $(25 \mathrm{~m})$ compared to the farther one $(100 \mathrm{~m})$. The subsidence also fluctuated, notably in the wet season, indicating the influence of rain event to peat subsidence. Rewetting peatland was likely to result in reducing peat subsidence suggesting the importance of water management in peatland to recover degraded peatland.
\end{abstract}

Keywords: peat, groundwater level, subsidence

\section{INTRODUCTION}

Cultivating deep peatlands for smallholder rubber plantation is a common practice in Pulang Pisau regency. Drainage canals have been extensively made to lowering groundwater table of peat swamp in order to provide appropriate zones for plant roots. However, this condition may result in the deterioration of peatlands, and hence the area which poses such a condition is classified as degraded peatlands.

Deep peat utilisation either by communities or government project may increase peatland degradation. Limin (2006) suggested that peatland exploitation for agricultural purposes is considered as an environmentally high-cost practice and results in many problems. Drainage canals construction in peatlands caused disruption of the hydrological cycle and previously stable ecosystem and therefore resulting in a susceptible environment. Peat swamp forest which already deforested and drained always encounter fire every year due to depleting hydrological function. Furthermore, indigenous peat swamp forest vegetation is likely more suitable and sustainable for community income sources compared to other land uses. Besides, the community empowerment programs have not successfully improved community welfare due to improper strategies.

Even though canals construction may have a benefit to increase peatland suitability for commercial purpose, this practice has adverse impacts. Agus et al. (2014) explained that increasing drainage and decreasing vegetation 
density are an indication of disturbed peat swamp forests which are considered as degraded peatlands. Furthermore, degraded peatlands are most likely be a source of greenhouse gas emission due to peat decomposition process. In addition, peat swamp forest conversion and canal construction also lead to depleting level of peatlands (peat subsidence) as an indication of degraded peatlands (Maswar and Agus, 2014).

Based on a research by Wahyunto, Nugroho, and Agus (2014), the maturity of peat in Jabiren, Pulang Pisau, Central Kalimantan on the first layer of $0-70 \mathrm{~cm}$ was sapric, $70-130 \mathrm{~cm}$ was hemic, and $130-500 \mathrm{~cm}$ was fibric. Furthermore, the study also found that clay was the substratum of the peatlands. Hikmatullah, Hidayat, and Suryana (2013) had characterised the soil and found that the soil had 0.21-0.23 g/ml bulk density, 3.4-4.0 of pH, 31.28-57.59\% of organic C, 66-126 $\mathrm{cmol}(+) / \mathrm{kg}$ of CEC, and low base saturation $(<10 \%)$. Based on those properties, Jabiren peatland was categorised as ombrogenous peat (poor peat), and the soil was classified to Typic Haplohemists and Sapric Haplohemists (Soil Taxonomy 2010).

Land suitability of Jabiren peatlands was classified as marginally suitable (S3) for dryland rice, maize, and rubber with the limitations were strongly acid soil $\mathrm{pH}$, low status of soil nutrient, and low to moderate level of ash content. Carbon stock of peatlands in ex ICCTF Plot in Jabiren (5.1 ha) was around 2500 to 3490 t/ha.

This study aimed to observe groundwater table and peat subsidence of degraded deep peatlands in ex ICCTF Plot in Jabiren, Central Kalimantan province.

\section{RESEARCH METHODOLOGY}

The study was undertaken from April to October 2019 in ex ICCTF (Indonesia Climate Change Trust Fund) 2012 plot. The plot situated in Jabiren village, Jabiren Raya district, Pulang Pisau Regency, Central Kalimantan province. It was a smallholder rubber plantation with 5.1 ha of total area, and the rubber trees were planted in 2008 developed from seedlings.

The parameter, including the groundwater table and peat subsidence, were observed weekly from April to October 2019. Groundwater table data were collected from 44 piezometers which had been previously installed and distributed on the research site. Groundwater table data consisted of the average of all piezometers and transect data. The transect data comprised several piezometer measurements from the front drainage canal to the rear one.

Subsidence data were recorded from 10 subsidence stick, divided into two groups based on the distance from the front canal, i.e. 25 and $100 \mathrm{~m}$ (Figure 1). The drainage canal was made in 2003 with $5 \mathrm{~m}$ width and $1.5 \mathrm{~m}$ depth connecting the canal of ex-Mega Rice Project and Kahayan River. 


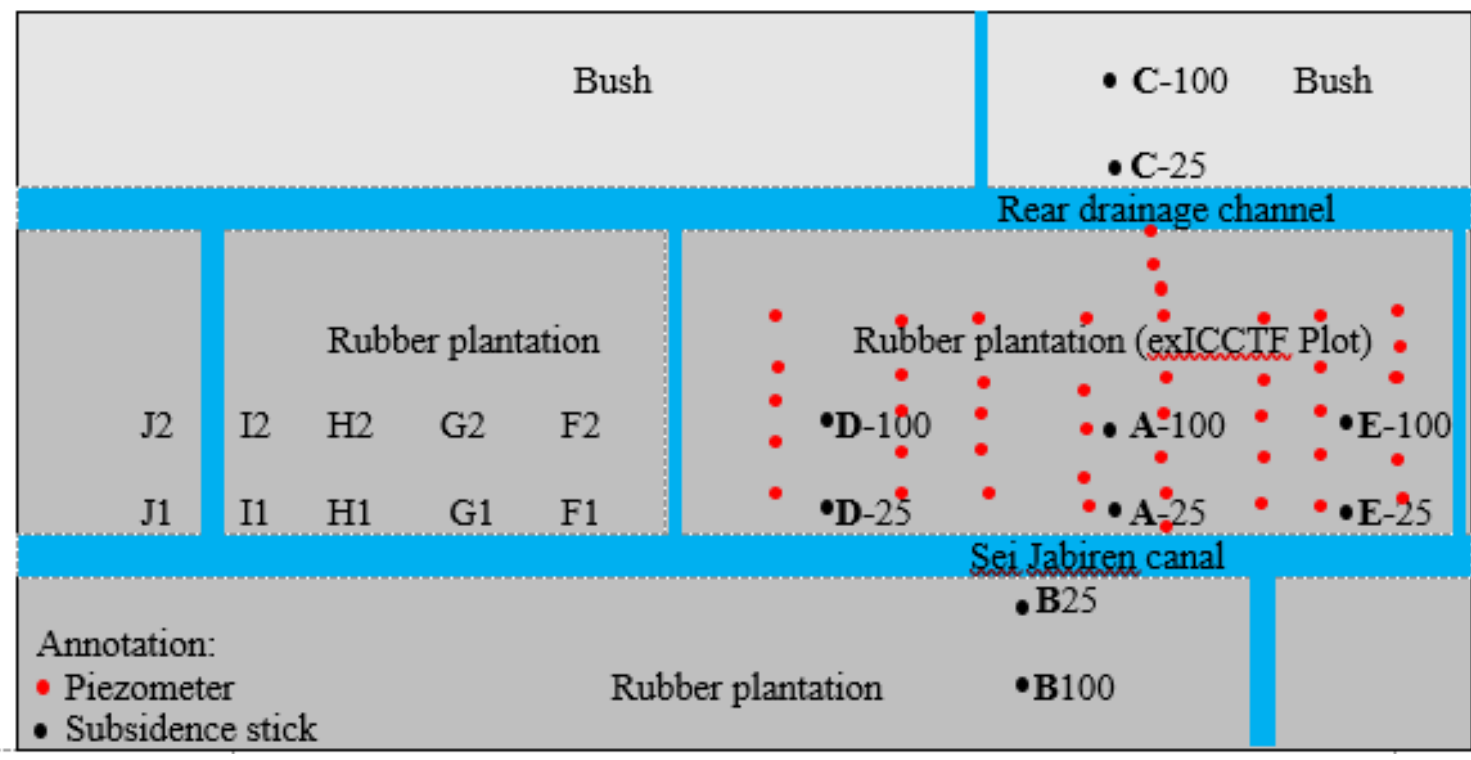

Figure 1. Peatland research layout, piezometer and peat subsidence position in ex-ICCTF plot in Jabiren, Central Kalimantan

\section{RESULTS AND DISCUSSION}

\section{Groundwater level characteristic}

Groundwater table of peatland was strongly affected by some factors, and one of them is the pattern of the wet and dry season. It has been found that the groundwater was moving upward to the peat surface on the rainy season, inversely, on the dry season, the groundwater level was moving downward farther from the surface (Figure 2). These findings confirm the previous study by Sosiawan, Kartiwa, Nugroho, and Syahbuddin (2017) which suggested that the ground water level of Jabiren peatland was influenced by rain event and the water level of river and canal.

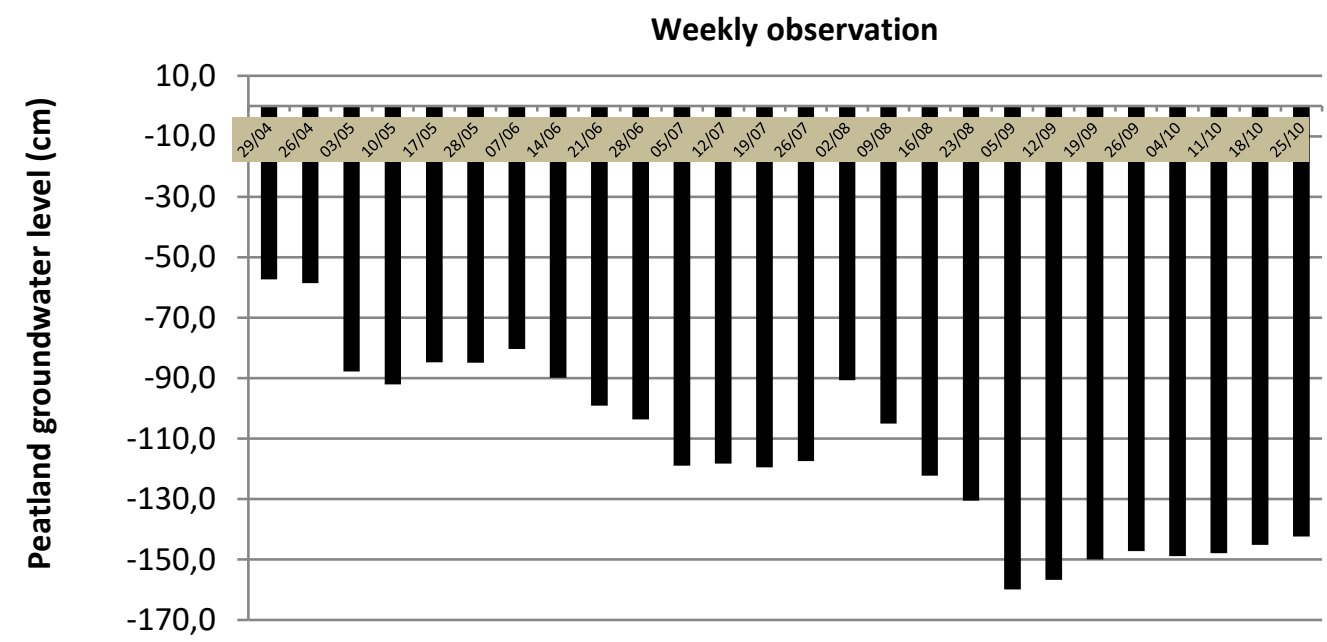

Figure 2. The average groundwater level observed weekly from April to October 2019 in ex ICCTF peatland plot in Jabiren, Central Kalimantan. 
Despite the presence of a water gate on the forepart of drainage canal built by The Republic of Indonesia Peat Restoration Agency (BRG) in 2018, the groundwater could not successfully be maintained on the level of $40 \mathrm{~cm}$ below the peat surface. Moreover, the groundwater level depletion even reached more than $150 \mathrm{~cm}$ depth on 5 and 12 September 2019. Since the area had groundwater table by $40 \mathrm{~cm}$ below the peat surface, it has been considered as a damaged or degraded peatland based on PP No. 57

\section{Tahun 2016.}

The behaviour of groundwater table which reached more than $40 \mathrm{~cm}$, and to a greater extent reaching $150 \mathrm{~cm}$ below the surface, implying the further peat degradation processes. This phenomenon indicates that the drainage canal had a critical effect on peatland over drying, primarily on the dry season. A good peatland water management would likely maintain groundwater table on $40 \mathrm{~cm}$ depth or less. Moreover, Wetlands International and Tropenbos International (2016) suggested that the sustainable water management in peatland could be implemented by the nil-drainage practice or by rewetting the peatland until the water approaches peat surface.

Groundwater level on peatland research site of ex ICCTF plot during the study was around 50 to $150 \mathrm{~cm}$ indicating the occurrence of peatland degradation. SarVision (2018) reported that the groundwater level of Indonesian peatlands was about 0 to $177 \mathrm{~cm}$ below the surface.

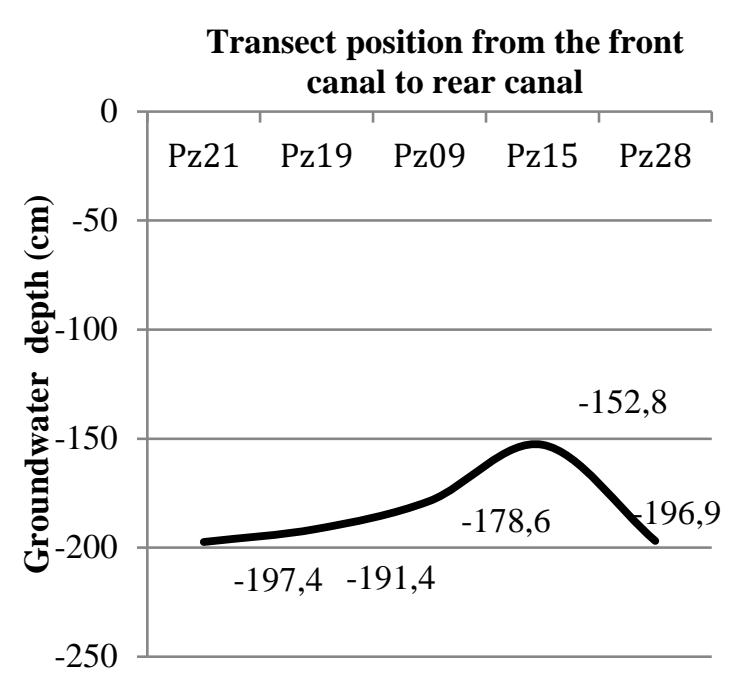

Figure 3. Transect observation of peat groundwater level from the front canal to rear canal in ex-ICCTF peatland plot in Jabiren, Pulang Pisau Regency, Central Kalimantan.

They reported that undisturbed peat swamp forest might have groundwater level approaching peat surface. On the other hand, degraded peatland (plantation) had varied groundwater level, ranged from 30 to $117 \mathrm{~cm}$ depth below the surface.

Based on the transect observation of peatland groundwater level on the research site, it has been found that the groundwater level was deeper approaching the canal. Inversely, the groundwater level was shallower on the location further away from the canal. Furthermore, the groundwater level formed the dome shape (Figure 3). These findings confirmed the previous studies by Aswandi, Sadono, Supriyo, and Hartono (2016) and (Wakhid, Nurzakiah, and Zainudin, 2019) which reported a similar phenomenon. It has been suggested that the phenomenon seems due to water nature, which flows to a 
lower place. Furthermore, this finding implies that the drainage channel influences the groundwater level in peatland.

Moreover, groundwater level of drained peatlands, either cultivated or abandoned, was likely to fluctuate and deep. Peat water management is critical since the groundwater level less than $50 \mathrm{~cm}$ in depth could minimise peat drought and fire risk (Herawati, Akbar, Farastika, and Azmeri, 2018). However, agricultural plants may require certain groundwater level to support optimum growth. Typically, groundwater level should be maintained on below the roots zone, in order to provide adequate water content and air, by controlling water level in tertiary channels (Wangsadipura, 2005).

\section{Peat subsidence}

Peat thickness in research site varied from $4.9 \mathrm{~m}$ to $10 \mathrm{~m}$, and the distance from the Kahayan river was similar, around 2 kilometres (Table 3). Indrayanti, Marsoem,
Prayitno, Supriyo, and Radjagukguk. (2015) suggested that the distance from the river does not influence peat thickness. The study reported that based on the observation of peat distribution in Kalampangan, peat thickness varied from $3.72 \mathrm{~m}$ to $6.2 \mathrm{~m}$. The highest peat thickness was found on the location $2.62 \mathrm{~km}$ from the river, and the lowest one was found in the distance of $2.9 \mathrm{~km}$.

Peat subsidence in ex ICCTF peatland plot ranged from 27.4 to $38.5 \mathrm{~cm}$ over seven years of observation from 2012 to 2019. It has been calculated that the average subsidence ranged from $0.3 \mathrm{~cm} / \mathrm{month}$ or $3.6 \mathrm{~cm} /$ year to 0.5 $\mathrm{cm} /$ month or $6.2 \mathrm{~cm} /$ year. Furthermore, the estimation of cumulative peat subsidence from the beginning of canal drainage construction in 2003 showed that the subsidence in such a location was about 54,2 to $93,6 \mathrm{~cm}$ in average (Table 3, Figure 4-5). To some extent, peat subsidence in the research site is still considered below the

Table 3. Peat thickness, cumulative peat subsidence, and peat subsidence rate (monthly and annually) of ex ICCTF peatland plot

\begin{tabular}{|c|c|c|c|c|c|c|}
\hline No. & $\begin{array}{c}\text { Subsidence stick } \\
*)\end{array}$ & $\begin{array}{l}\text { Peat thickness } \\
\text { (m) }\end{array}$ & $\begin{array}{l}\text { monthly } \\
(\mathrm{cm} / \mathrm{mo})\end{array}$ & $\begin{array}{l}\text { annualy } \\
(\mathrm{cm} / \mathrm{yr})\end{array}$ & $\begin{array}{c}\text { Cumulative } \\
\text { subsidence } \\
2012 / 2013-2019 \\
(\mathrm{~cm})\end{array}$ & $\begin{array}{c}\text { Cumulative } \\
\text { subsidence } \\
\text { estimation 2003- } \\
2019 \\
(\mathrm{~cm})\end{array}$ \\
\hline 1 & A-25 & 6.20 & 0.43 & 5.15 & 38.75 & 77.18 \\
\hline 2 & A-100 & 6.28 & 0.30 & 3.61 & 27.38 & 54.16 \\
\hline 3 & B-25 & 10.00 & 0.37 & 4.50 & 34.10 & 67.45 \\
\hline 4 & B-100 & 4.87 & 0.30 & 3.64 & 27.60 & 54.59 \\
\hline 5 & $\mathrm{C}-25$ & 4.87 & 0.39 & 4.69 & 35.60 & 70.42 \\
\hline 6 & C-100 & 5.15 & 0.35 & 4.17 & 31.60 & 62.51 \\
\hline 7 & D-25 & 6.45 & 0.43 & 5.12 & 31.60 & 76.86 \\
\hline 8 & D-100 & 6.50 & 0.38 & 4.60 & 28.40 & 69.10 \\
\hline 9 & E-25 & 5.60 & 0.52 & 6.24 & 38.50 & 93.65 \\
\hline 10 & E-100 & 5.72 & 0.43 & 5.17 & 31.90 & 77.60 \\
\hline
\end{tabular}

*) $25,100=$ the distance from the canal (meter); subsidence stick A, B, and C were installed on 12 April 2012; subsidence stick D and E were installed on 19 September 2013. 
highest average of peat subsidence rate of a study by Hooijer et al. (2012), which was around 5 to $5.4 \mathrm{~cm} /$ year. Nevertheless, there was a location in ex ICCTF plot having the greater peat subsidence compared to their study, i.e. subsidence stick E25 (6.2 cm/year). Hooijer et al. (2012) mentioned that the main factor of peat subsidence during the first five years of drainage practice is compaction. Afterwards, peat oxidation is likely to be the critical factor of peat subsidence during the latter five years and subsequent years.

The depletion of the peatland surface level was triggered by improper management practice. Some reasons for the depletion (subsidence) of peatland are deforestation, drainage, and fire (Murdiyarso, Hergoualc'h, Sasmito, and Hanggara, 2017). The drainage practice not only decreases groundwater level but also increases organic matter decomposition resulting in peat subsidence (Murdiyarso et al., 2018).

Peat subsidence process, as suggested by Agus and Subiksa (2008); Bintang, Rusman, Basyarudin, and Harahap (2005), involves four main components. The first component is consolidation, which is the compaction of peat due to drainage. Groundwater level depletion causes the increasing pressure from upper peat layer to the peat layer below the water table, and hence, peat becomes consolidated. The second component is the shrinking process, i.e. decreasing volume of peat layer above the groundwater table due to drainage or drying mechanism. Decomposition or oxidation is the next component which results in decreasing peat mass due to aerobic condition. Finally, the last component, i.e. fire, significantly decreases peat volume.

There was a steady pattern of peat subsidence with respect to the distance from the drainage canal. Deeper subsidence was found at the location near to drainage canal ( 25 $\mathrm{m})$, while shallower subsidence was found at the location further away from the canal (100 $\mathrm{m})$. This finding is consistent with a study by Aswandi et al. (2016) which stated that the highest subsidence rate existed on the nearest location from the canal. They reported that the depletion of peat surface level may reach 4.9 $\mathrm{cm} /$ year at the distance of $3 \mathrm{~m}$ from the canal. However, peat subsidence rate was reported to decrease by $3.3 \mathrm{~cm} /$ year at the distance of 50 $m$ from the edge of the canal. Hashim, Teh, and Ahmed (2019) found that increasing peat subsidence is in line with the increasing depth of groundwater table. This finding matches with our results that the highest subsidence was found at the location nearest to the canal which had the deepest groundwater table.

A study by Edi, Barus, and Baskoro (2017) in Bengkalis Island reported that peat subsidence of 0-50 $\mathrm{cm}$ existed at the location with $0-50 \mathrm{~cm}$ peat depth (peaty soils). However, the subsidence of $50-100 \mathrm{~cm}$ occurred on the location with more than $3 \mathrm{~m}$ peat depth, and the higher subsidence (more than $100 \mathrm{~cm}$ ) was found in the deep peatland. Based on the stepwise analysis, they suggested that peat subsidence was significantly 
influenced by some factors including plant age, land use, bulk density 50-100 cm, groundwater table, drainage canal water level, and distance from the canal.

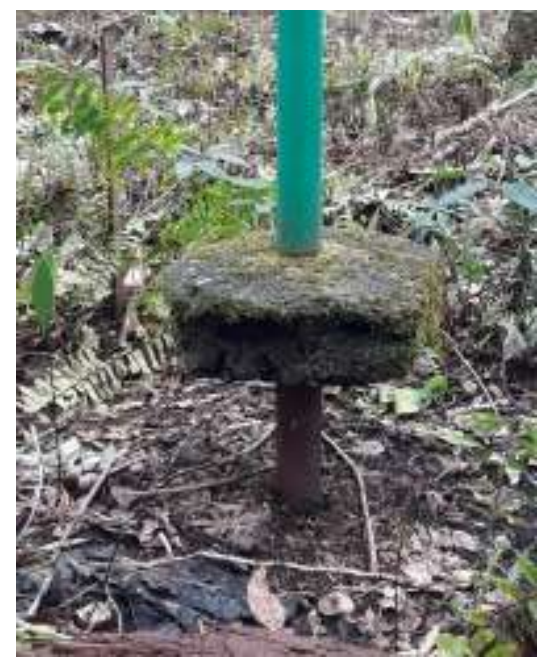

Figure 4. Subsidence stick A-25, located in a maintaned rubber plantation, at $25 \mathrm{~m}$ distance from the canal, peat subsidence was massive.

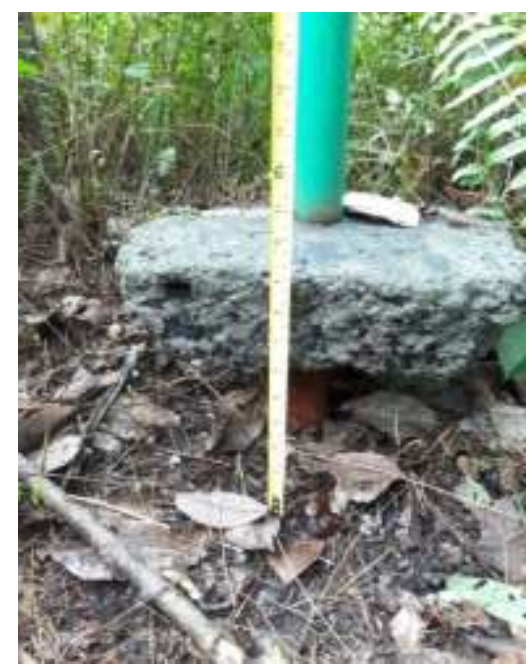

Figure 5. Subsidence stick A-100, located in a maintained rubber plantation, at $100 \mathrm{~m}$ distance from the canal, peat subsidence was less massive.

Furthermore, depleting organic matter content as a consequence of land management alteration may also cause peat subsidence (Deverel and Leighton, 2010). Turmudi, Suwarno, Nahib, Suryanta, and Niendyawati
(2016) reported that $90 \%$ of peatlands in Meranti islands had more than $3 \mathrm{~m}$ peat depth, and the subsidence was 4-7 cm/year on average.

Measurement of peat subsidence at a particular time may result in a lower value though the higher number was recorded at previous observation. The absence of rain caused the increasing peat subsidence; however, when the rain existed, rewetting peat may lead to increasing peat surface level. Increasing peat volume due to water recharging from the river as a result of increasing precipitation was found to reduce peat subsidence rate. A previous study by Sosiawan et al. (2017) suggested that the groundwater level in Jabiren peatland was influenced by rain event and surface water level of river and drainage channel. Spatial variation of groundwater level on research site showed that groundwater level was higher on piezometers that were farther away from the drainage channel. Moreover, based on land hydro topography observation, groundwater elevation on research site formed dome-shape indicating that ICCTF Jabiren plot had not posed significant subsidence

The adverse impact of peat subsidence, i.e. decreasing peat function as water storage resulted from depleting peat volume, may encompass either a smaller area (on-site) or a larger area (out-site) (Dariah and Maswar, 2014). 


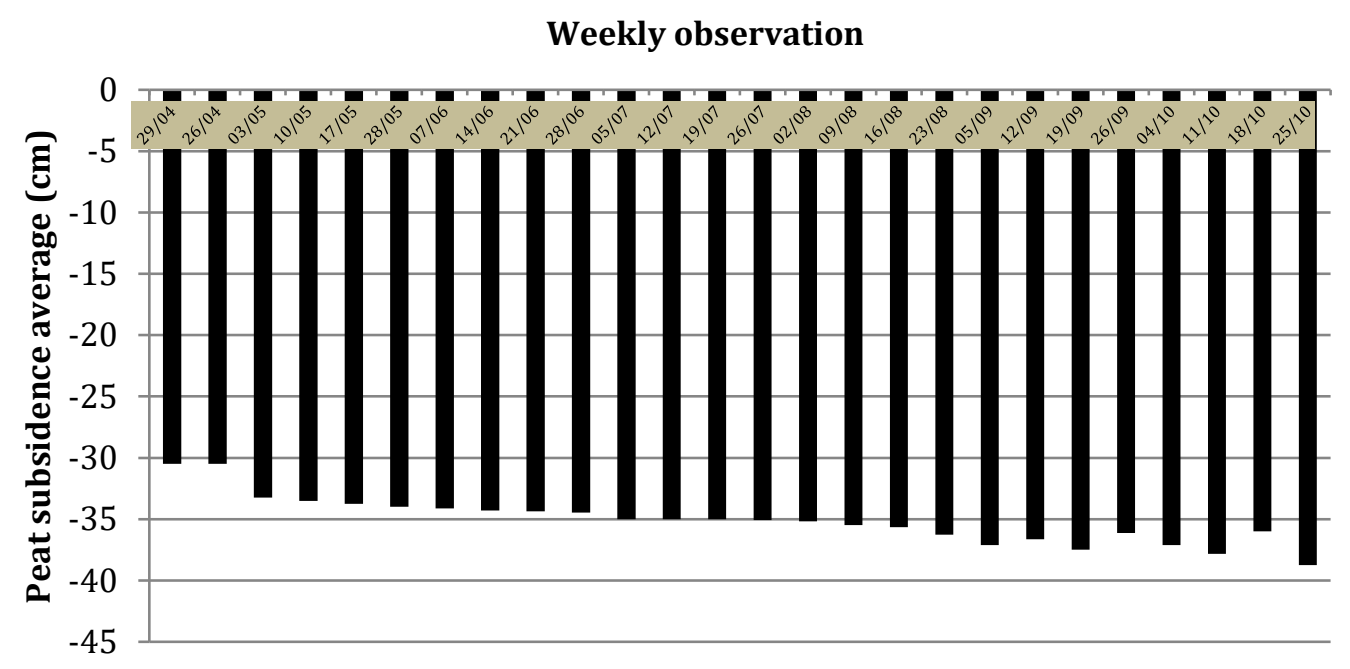

Figure 6. Weekly peat subsidence over 26 weeks observation (April to October 2019) in ex ICCTF plot in Jabiren.

Declining peat buffering function also increases the possibility of flooding during the rainy season and drought on dry season. A deeper groundwater level would reduce peat surface water content resulting in elevating peat sensitivity to fire, primarily on the dry season (Ratnaningsih and Prastyaningsih, 2017).

Wetlands International and Tropenbos International (2016) suggested that peat subsidence is inevitable irrespective of whether the water level is maintained at 40 or $50-80 \mathrm{~cm}$. The peatland water management and production system based on undrained or re-wetted peat would be considered as a truly sustainable approach. Such a condition where the water level will be close to the surface and which has a permanent cover would likely be the only way to stop subsidence.

\section{CONCLUSION}

Water level below the peat surface in ICCTF peatland plot in Jabiren fluctuated from
$57.3 \mathrm{~cm}$ on the rainy season and $159.9 \mathrm{~cm}$ on the peak of the dry season. Maintaining water level by $40 \mathrm{~cm}$ or less below the peat surface is unlikely to happen in the research site. Deeper peat subsidence occurred on the location adjacent to the drainage canal. The peat subsidence was 35.71 on the distance of $25 \mathrm{~m}$ the canal, and lower subsidence by 29.5 was found on a farther location, i.e. $100 \mathrm{~m}$ from the canal. Rewetting peatland is likely to result in lowering peat subsidence suggesting the importance of water management in peatland to recover degraded peatland.

\section{REFERENCES}

Agus, F. and I. G. M. Subiksa. 2008. Lahan gambut: Potensi untuk pertanian dan aspek lingkungan [Peatland: Agricultural Potential and Environmental Aspect]. Balai Penelitian Tanah dan World Agroforestry Centre (ICRAF). Bogor, Indonesia.

Agus, F., Wahyunto, H. Sosiawan, I. G. M. Subiksa, P. Setyanto, A. Dariah, ... I. Las. 2014. Pengelolaan berkelanjutan lahan gambut terdegradasi: trade-off keuntungan 
ekonomi dan aspek lingkungan [Sustainable management of degraded peatland: trade-off between economic and environmental benefits]. In: Prosiding Seminar Nasional Pengelolaan Berkelanjutan Lahan Gambut Terdegradasi untuk Mitigasi Emisi GRK dan Peningkatan Nilai Ekonomi. Jakarta, 18-19 Agustus 2014. pp 1-23.

Aswandi, A., R. Sadono, H. Supriyo, and H. Hartono. 2016. Kehilangan karbon akibat drainase dan degradasi lahan gambut tropika di Trumon dan Singkil Aceh. [Carbon loss from drainaged and degradation of tropical peatland in Trumon and Singkil, Aceh]. Jurnal Manusia dan Lingkungan. 23(3): 334-341.

doi:https://doi.org/10.22146/jml.18807

Bintang, B. Rusman, Basyarudin, and E. M. Harahap. 2005. Kajian subsidensi pada lahan gambut di Labuhan Batu Sumatera Utara. [The Assessment of subsidence of peatsoil in Labuhan Batu Sumatera Utara area]. Jurnal Ilmiah Ilmu-Ilmu Pertanian Agrisol. 4(1): 35-41

Dariah, A. and Maswar. 2014. Isu lingkungan gambut tropika Indonesia [Environmental issue of Indonesian tropical peatland]. In F. Agus, M. Anda, A. Jamil, \& Masganti (Eds.), Lahan Gambut Indonesia: Pembentukan, Karakteristik, dan Potensi Mendukung Ketahanan Pangan (Edisi Revisi) (pp. 101-129). IAARD Press. Jakarta.

Deverel, S. J. and D. A. Leighton. 2010. Historic, Recent, and Future Subsidence, Sacramento-San Joaquin Delta, California, USA. San Francisco Estuary and Watershed Science. 8(2): 1-23

Edi, H., B. Barus, and D. P. T. Baskoro. 2017. Pemetaan subsidendi kesatuan hidrologi gambut Sungai Jangkang - Sungai Liong Pulau Bengkalis. [Mapping of peatland subsidence in peat hydrology unit Jangkang River - Liong River in Bengkalis Island]. $J$. Il. Tan. Lingk. 19(1): 13-18

Hashim, S. A., C. B. S. Teh, and O. H. Ahmed. 2019. Influence of water table depths, nutrients leaching losses, subsidence of tropical peat soil and oil palm (Elaeis guineensis Jacq.) seedling growth. Malaysian Journal of Soil Science. 23: 1330
Herawati, H., A. A. Akbar, D. Farastika, and Azmeri. Water table evaluation post the construction of canal blocks on peatland in West Kalimantan, Indonesia. In: MATEC Web of Conferences, Vol 195. Solo Baru, Indonesia, 11-12 July 2018. pp 1-8.

Hikmatullah, H. Hidayat, and U. Suryana. Pemetaan detail tanah gambut di Plot Jabiren Kalimantan Tengah mendukung penelitian emisi karbon [Detailed mapping of peat soil in Jabiren plot Central Kalimantan for supporting carbon emission research]. Bogor, pp 113-127.

Hooijer, A., S. Page, J. Jauhiainen, W. A. Lee, X. X. Lu, A. Idris, and G. Anshari. 2012. Subsidence and carbon loss in drained tropical peatlands. Biogeosciences. 9(3): 1053-1071. doi:10.5194/bg-9-1053-2012

Indrayanti, L., S. N. Marsoem, T. A. Prayitno, H. Supriyo, and B. Radjagukguk. 2015. Distribusi ketebalan gambut dan sifat-sifat tanah di hutan rawa gambut Kalampangan, Kalimantan Tengah. [The thickness distribution of peat land and the properties of peat land at peat swamp forest Kalampangan, Central Kalimantan]. Wanatropika: $56-72$

Limin, S. H. 2006. Pemanfaatan lahan gambut dan permasalahannya [Peatland utilization and the problems]. Paper presented at the Workshop Gambut Dengan Tema: Pemanfaatan Lahan Gambut Untuk Pertanian, Tepatkah? Kerjasama antara Badan Pengkajian dan Penerapan Teknologi (BPPT) dan Kementerian Koordinator Kesejahteraan Rakyat. Jakarta, 22 November 2006.

Maswar and F. Agus. 2014. Cadangan karbon dan laju subsiden pada beberapa jenis penggunaan lahan dan lokasi lahan gambut tropika Indonesia [Carbon stock and subsidence rate of some landuses and location of Indonesian tropical peatland]. In F. Agus, M. Anda, A. Jamil, \& Masganti (Eds.), Lahan Gambut Indonesia: Pembentukan, Karakteristik, dan Potensi Mendukung Ketahanan Pangan (Edisi Revisi) (pp. 333-344). IAARD Press. Jakarta.

Murdiyarso, D., G. Anshari, D. A. Wijaya, A. Darmawan, A. Budiman, W. J. Purwanto, . . . T. Rusolono. (2018). Penentuan tingkat 
rujukan (reference level) untuk menduga penurunan emisi dari restorasi gambut. Badan Restorasi Gambut. Retrieved from https://www.winrock.org/document/penent uan-tingkat-rujukan-reference-level-untukmenduga-penurunan-emisi-dari-restorasigambut/

Murdiyarso, D., K. Hergoualc'h, S. D. Sasmito, and B. Hanggara. (2017). Measuring subsidence: Detected from surface elevation change. In CIFOR (Ed.). Bogor.

Ratnaningsih, A. T. and S. R. Prastyaningsih. 2017. Dampak kebakaran hutan gambut terhadap subsidensi di hutan tanaman industri. [The impact of peat fire on subsidence in industrial forest]. Wahana Forestra. 12(1): 37-43. doi:https://doi.org/10.31849/forestra.v12i1. 200

SarVision. (2018). Pilot ecosystem account for Indonesian peatlands: Sumatra and Kalimantan islands. SarVision Wageningen and Wageningen University the Netherlands. Retrieved from http://documents1.worldbank.org/curated/e n/280931564033874140/pdf/Pilotecosystem-account-for-Indonesianpeatlands-Sumatra-and-Kalimantanislands.pdf

Sosiawan, H., B. Kartiwa, W. T. Nugroho, and H. Syahbuddin. 2017. Variasi temporal dan spasial tinggi muka air tanah gambut lokasi demplot ICCTF Jabiren Kalimantan Tengah. J. Tanah dan Air. 14(2): 68-82

Turmudi, Y. Suwarno, I. Nahib, J. Suryanta, and Niendyawati. 2016. Pengelolaan lahan gambut dan dampak subsiden yang ditimbulkannya: Studi kasus Kepulauan Meranti, Provinsi Riau [Peat land management and its caused impact of subsidence: Case study Meranti Islands, Riau Province]. In: Prosiding Seminar nasional geomatika 2016: Peran geospasial dalam membingkai negara kesatuan Republik Indonesia. Cibinong, 5 October 2016. pp 217 - 226.

Wahyunto, K. Nugroho, and F. Agus. 2014. Perkembangan pemetaan dan distribusi lahan gambut di Indonesia [Carbon stock and subsidence rate of some landuses and location of Indonesian tropical peatland]. In F. Agus, M. Anda, A. Jamil, \& Masganti (Eds.), Lahan Gambut Indonesia: Pembentukan, Karakteristik, dan Potensi Mendukung Ketahanan Pangan (Edisi Revisi) (pp. 33-60). IAARD Press. Jakarta.

Wakhid, N., S. Nurzakiah, and Zainudin. 2019. Dinamika tinggi muka air tanah pada lahan gambut yang terbakar. EnviroScienteae. 15(1): 86-90. doi:http://dx.doi.org/10.20527/es.v15i1.632 7

Wangsadipura, M. 2005. Analisis Hidraulik Aliran Bawah Permukaan Melalui Media Gambut (Studi Kasus Lahan Perkebunan Kelapa di Guntung-Riau). Jurnal Teknik Sipil. 12(1): 21-34. doi:http://dx.doi.org/10.5614\%2Fjts.2005.1 2.1.3

Wetlands International and Tropenbos International. (2016). Peatland Brief: Can Peatland Landscapes in Indonesia be Drained Sustainably? An Assessment of the 'eko-hidro' Water Management Approach. Wetlands International Report. Retrieved from

https://www.wetlands.org/publications/peat land-brief-an-assessment-of-the-eko-hidrowater-management-approach/ 